\title{
WYSOKI PRZEDSTAWICIEL UNII DS. ZAGRANICZNYCH I POLITYKI BEZPIECZEŃSTWA - NA STYKU UNIJNEJ EGZEKUTYWY I DZIAŁAŃ ZEWNĘTRZNYCH. WYBRANE ZAGADNIENIA
}

1. Wyjątkowy charakter Unii Europejskiej (UE) w sposób dość naturalny skłania do prób aplikowania względem niej idei i koncepcji właściwych państwu. Unijna władza wykonawcza oraz polityka zagraniczna wydają się w tym świetle obszarami szczególnie intrygującymi. Oba wykazują bowiem szereg cech specyficznych, pozostają jednocześnie w silnym związku.

Wyczerpująca analiza obu kategorii w żadnej mierze nie jest ambicją poniższych rozważań. Są one raczej zbiorem refleksji poświęconych unijnej egzekutywie oraz działaniom zewnętrznym. Uzupełnią je uwagi poświęcone Wysokiemu Przedstawicielowi UE ds. Zagranicznych i Polityki Bezpieczeństwa (dalej Wysoki Przedstawiciel, WP) jako organowi egzekutywy operującemu w sferze unijnych spraw zagranicznych. W konsekwencji dalsze rozważania koncentrują się wokół zagadnień wybranych, a szereg wątków zostanie jedynie zasygnalizowanych bądź w ogóle pominiętych. Ujęcie to, wychodząc naprzeciw założeniom redakcyjnym, wydaje się jednocześnie korespondować z założeniami badawczymi całego tomu.

2. Unia Europejska jako organizacja międzynarodowa ${ }^{1}$ wykazuje pewną specyfikę, którą w warstwie terminologicznej relatywnie często wyraża pojęcie organizacja ponadnarodowa ${ }^{2}$. Uwagę w tym kontekście zwracają: charakter i zakres przekazanych Unii przez państwa członkowskie kompetencji oraz atrybuty tworzonego przez Unię na tych podstawach prawa. Nie bez znaczenia pozostaje też fakt, iż prawo to „obudowane” jest szeregiem instytucji i procedur o profilu implementacyjnym i kontrolnym, angażujących ciała unijne. W sporym uproszczeniu, można zatem stwierdzić, iż w zakresie powierzonych jej kompetencji Unia, w pewnym sen-

\footnotetext{
1 Por. m.in. J. Barcz, Charakter prawny Unii Europejskiej, (w:) J. Barcz (red.), Ustrój Unii Europejskiej, Warszawa 2010, s. I-25.

2 Ibidem, s. I-33, zob. także: K. Lenaerts, P. van Nuffel, R. Bray, N. Cambien, European Union Law, London 2011, s. $16-24$.
} 
sie, „wyręcza” państwa członkowskie jako podmiot realizujący funkcje władcze. Ów szczególny charakter UE jako organizacji międzynarodowej w wielu wymiarach zdaje się ,zbliżać” ją do państwa ${ }^{3}$. W efekcie trudno a priori wykluczyć adaptowanie do unijnych warunków konstrukcji właściwych państwu, łącznie z zasadą podziału władzy i próbą wyodrębnienia poszczególnych jej gałęzi ${ }^{4}$. Inna perspektywa nawiązuje do ogólnego pojęcia „system polityczny"5 i pozwala naturę Unii rozpatrywać w szerszym wymiarze niż sztywny schemat porównawczy: Unia - organizacja międzynarodowa bądź Unia - państwo ${ }^{6}$. Ponieważ UE spełnia właściwe kryteria, by za system polityczny ją uznać ${ }^{7}$, zagadnienia związane z funkcjonowaniem jakiegokolwiek tego rodzaju systemu również w odniesieniu do Unii zachowują aktualność. W tym ujęciu UE być może nie posiada właściwego „rządu”, posiada jednak własną legislatywę, egzekutywę (jakkolwiek ,podzieloną” - multi-headed) i sądownictwo ${ }^{8}$. Poszukiwanie w ramach UE władzy wykonawczej (a nawet podziału władzy) nie jest więc bezzasadne, choć ewentualne wnioski w tej mierze muszą uwzględniać charakter Unii ${ }^{9}$.

Ślady funkcji wykonawczych UE dostrzegalne są w traktatach stanowiących podstawy Unii ${ }^{10}$. Oto art. 17 TUE nawiązuje wprost do funkcji wykonawczych Komisji, art. 291 TFUE (w polskiej wersji językowej) posługuje się z kolei pojęciem akty wykonawcze. Stwierdzenie, iż określone funkcje - nazwane w uproszczeniu wykonawczymi - są Unii i jej instytucjom przypisane samo w sobie nie musi jednak przesądzać o istnieniu w UE w pełni ukształtowanej władzy wykonawczej. Traktaty szerszych podstaw dla tego rodzaju tez nie gwarantują. W sposób jednoznaczny i pełny podziału władzy nie wprowadzają ${ }^{11}$, nie identyfikują również precyzyjnie i nie definiują samej władzy wykonawczej ${ }^{12}$. Sięgając jednak do klasycznych teorii dotyczących egzekutywy można podjąć próbę odnalezienia w systemie Unii funkcji

Por. M. Poboży, Zasada podziału władzy w systemie instytucjonalnym Unii Europejskiej, Warszawa 2014, s. 52, 142-143.

Por. G. Conway, Recovering a Separation of Powers in the European Union, „European Law Journal”, vol. 17, No. 3, May 2011, s. 304, 322. W polskiej literaturze zob. M. Poboży, Zasada..., op. cit., s. 52, 142-143. S. Hix, B. Høyland, The Political System of the European Union, Basingstoke 2011, s. 12-14.

6 D. Curtin, Accumulated executive power in Europe. The "most dangerous" branch of government in the European Union, Amsterdam 2009, s. 12-13.

7 S. Hix, B. Høyland, The Political System..., op. cit., s. 12-14.

8 D. Curtin, Accumulated..., op. cit., s. 13.

9 R. Grzeszczak zwraca na przykład uwagę na „niebezpieczeństwa” wynikające z odmienności perspektyw systemowych i powstające $w$ tym kontekście pytanie, czy określone pojęcia oznaczają to samo w unijnym porządku prawnym, co w wewnętrznych porządkach prawnych. Zob. R. Grzeszczak, Władza wykonawcza w systemie Unii Europejskiej, Warszawa 2011, s. 227.

10 Traktat o Unii Europejskiej i Traktat o funkcjonowaniu Unii Europejskiej (wersje skonsolidowane), Dz.Urz. UE C 326 z 26.10.2012.

11 Por. R. Grzeszczak, Władza wykonawcza..., op. cit., s. 123-124, 184, R. Grzeszczak, W poszukiwaniu locus władzy wykonawczej w Unii Europejskiej, Nowa Politologia, s. 1, 4, http://www.nowapolitologia.pl/sites/default/files/ articles/w-poszukiwaniu-locus-wladzy-wykonawczej-w-unii-europejskiej-540.pdf (data dostępu: 28.09.2015 r.). Na temat podziału władzy w UE zob. m.in.: K. Lenaerts, Some Reflections on the Separation of Powers in the European Community, „Common Market Law Review”, Vol. 28 (1991), No. 1 oraz cytowane już opracowania G. Conway’a oraz M. Poboży. 
tradycyjnie przypisywanych władzy wykonawczej i określenia podmiotów funkcje te realizujących ${ }^{13}$.

W ramach funkcji egzekutywy P. Craig identyfikuje: ustalanie ogólnych priorytetów i agendy działań ustawodawczych, realizację polityki zagranicznej i obronnej, kształtowanie budżetu oraz wdrażanie polityk i legislacji ${ }^{14}$. Wydaje się, iż tak sformułowane funkcje są przez UE realizowane, możliwe jest też ich przyporządkowanie poszczególnym instytucjom. Za określanie ogólnych kierunków i priorytetów politycznych w funkcjonowaniu UE odpowiedzialna jest Rada Europejska, nadająca Unii (art. 15 TUE) impulsy niezbędne do jej rozwoju. Programowa funkcja przypisana jest również, do pewnego stopnia, Radzie (art. 16 ust. 1 TUE), a także Komisji (art. 17 ust. 1 TUE), jakkolwiek w węższym zakresie. Polityka zagraniczna z kolei pozostaje domeną Rady Europejskiej i Rady. Wiąże się to m.in. z relatywnie największym zaangażowaniem wskazanych instytucji w rozwój wspólnej polityki zagranicznej i bezpieczeństwa (WPZiB) Unii Europejskiej (m.in. art. 25 ust. 1 TUE) ${ }^{15}$. Określanie unijnego budżetu to obszar zainteresowania i kompetencji Rady oraz Parlamentu (art. 14 ust. 1, art. 16 ust. 1 TUE), choć daleko idące uprawnienia posiada w tym zakresie również Komisja, która budżet wykonuje (art. 17 ust. 1 TUE, art. 314, 317 TFUE). Wreszcie, efektywna implementacja prawa UE - w zakresie, w jakim nie odbywa się na płaszczyźnie państw członkowskich ${ }^{16}$ - wydaje się pozostawać funkcją przypisaną przede wszystkim Komisji ${ }^{17}$.

Powyższy schemat ma, siłą rzeczy, charakter pewnego skrótu i nie uwzględnia wszelkich niuansów oraz specyfiki unijnej egzekutywy. Stanowi jednak uproszczony i dość ogólny obraz unijnej władzy wykonawczej - władzy specyficznej, władzy „dzielonej”" ${ }^{18}$, niemniej władzy możliwej do zidentyfikowania tak w wymiarze funkcjonalnym, jak i organizacyjnym ${ }^{19}$.

3. Jeśli realizacja polityki zagranicznej przypisana jest egzekutywie, wypada poczynić kilka uwag na temat tego rodzaju aktywności na płaszczyźnie unijnej ${ }^{20}$.

13 Możliwość takiego podejścia sugerowana jest w literaturze, por. R. Grzeszczak, ibidem.

14 P. Craig, European Governance: Executive and Administrative Powers under the New Constitutional Settlement, (w:) Weiler, Eisgruber (eds.), Altneuland: The EU Constitution in a Contextual Perspective, Jean Monnet Working Paper 5/04, s. 4, http://jeanmonnetprogram.org/archive/papers/04/040501-12.pdf (data dostępu: 30.09 .2015 r.). Podobne stanowisko prezentowane jest także w polskiej literaturze, por. M. Poboży, Zasada podziału władzy..., op. cit., s. 198; R. Grzeszczak, W poszukiwaniu..., op. cit., s. 7.

15 Jakkolwiek polityka ta nie wyczerpuje całości działań zewnętrznych UE.

16 Z racji na ograniczone ramy opracowania pominięte zostaną analizy dotyczące podziału funkcji (władzy) wykonawczej między UE i państwa członkowskie. Zasygnalizować jednak należy, iż przy ich klasycznym ujęciu funkcje wykonawcze realizowane są w bardzo szerokim zakresie przez te państwa właśnie, co wynika m.in. z zasad stosowania prawa UE oraz specyfiki aktów unijnego prawa wtórnego.

17 Artykuł 17 ust. 1 TUE wymienia szereg kompetencji i zadań Komisji, które - wręcz intuicyjnie - mieszczą się w powszechnym sposobie pojmowania egzekutywy jako implementacji ustawodawstwa.

18 Por. R. Grzeszczak, Władza wykonawcza..., op. cit., s. 183.

19 Trudno jednak wyodrębnić w sposób jednoznaczny instytucjonalny rdzeń unijnej władzy wykonawczej.

20 Szeroko na ten temat m.in. w: P. Eeckhout, EU External Relations Law, Oxford 2011, P.J. Cardwell (ed.), EU External Relations Law and Policy in the Post-Lisbon Era, The Hague 2012. 
Wątpliwości budzić może już adekwatność pojęcia „polityka zagraniczna” w odniesieniu do podmiotu innego niż państwo. Unia dysponuje jednak stosunkowo szerokim zapleczem polityczno-prawnym i instytucjonalnym pozwalającym jej prowadzić działalność w obszarze spraw zagranicznych, a treść traktatów daje podstawy do identyfikacji szeregu kompetencji UE (wyrażonych wprost lub domniemanych) w tej materii. Stworzono w ten sposób swego rodzaju „mozaikę" różnorodnych, wyodrębnionych traktatowo dziedzin oraz właściwych im instrumentów, procedur i instytucji generujących fundament unijnej aktywności zewnętrznej. Wydaje się, iż umownie, w uproszczeniu i dla potrzeb niniejszego opracowania, rzeczywiście polityką zagraniczną nazywać ją można ${ }^{21}$.

Zdolność UE do podejmowania działań w przestrzeni zewnętrznej wydaje się przy tym pozostawać poza sporem. Tradycyjnie organizacje międzynarodowe postrzegane są jako forma współpracy państw, ustanowiona na mocy umowy międzynarodowej, posiadająca określone organy i kompetencje oraz zmierzająca do realizacji wspólnych celów ${ }^{22}$. Można więc stwierdzić, iż zakres i charakter zadań postawionych przed Unią stanowi pewien fundament dla zakresu przyznanych jej kompetencji. Wachlarz powierzonych Unii zadań jest niezwykle szeroki, a możliwość efektywnego osiągania owych wspólnych celów (por. art. 2 TUE) wymaga podejmowania określonych działań, również w sferze spraw zagranicznych. Nie ulega bowiem wątpliwości, iż nawet z perspektywy realizacji celów stricte wewnętrznych, określona aktywność zagraniczna bywa konieczna.

Tego rodzaju aktywność Unii w formalnym ujęciu traktatowym określana jest mianem „działań zewnętrznych UE”, które w ten sposób stają się kategorią centralną. To obszar traktatowo wyodrębniony, choć niejednorodny i zróżnicowany wewnętrznie. Obejmuje on wspólną politykę zagraniczną i bezpieczeństwa (WPZiB), podlegającą szczególnym zasadom i procedurom, oraz szereg dziedzin i instrumentów ${ }^{23}$ wpisanych w tzw. reżim wspólnotowy/unijny. Rozwarstwienie to oznacza m.in., iż w poszczególnych obszarach działań zewnętrznych dostępne są odmienne instrumenty prawne przyjmowane w odmiennych procedurach. Nadto, w zależności od rozpatrywanego obszaru, w różny sposób kształtuje się zakres unijnych kompetencji, a także stopień zaangażowania unijnych instytucji. Warto także dodać, iż w ujęciu formalnym, na marginesie działań zewnętrznych, pozostaje szereg aktywności UE w ramach polityk i działań wewnętrznych ${ }^{24}$, które jednak ze swej natury wiążą się ściśle ze sferą spraw zagranicznych ${ }^{25}$. państwa i jego organów, por. D. Nohlen (Hrsg.), Wörterbuch Staat und Politik, Bonn 1998, s. 33-36, W. Woyke (Hrsg.), Handwörterbuch Internationale Politik, Bonn 1998, s. 1-6. packi, Encyklopedia Organizacji Międzynarodowych, Warszawa 1999, s. 14.

23 M.in.: wspólna polityka handlowa, współpraca na rzecz rozwoju czy pomoc humanitarna.

24 Dotyczy to np. polityk w zakresie kontroli granic, azylu i migracji stanowiących element Przestrzeni wolności, bezpieczeństwa i sprawiedliwości.

25 Zob. S. Keukeleire, T. Delreux, The Foreign Policy of the European Union, Basingstoke 2014, s. 11-14. 
Owa głęboka wewnętrzna niejednorodność działań zewnętrznych Unii wydaje się przy tym zrozumiała i naturalna. Działalność UE w sferze spraw zagranicznych jest bowiem pochodną zróżnicowania celów Unii, powierzonych jej zadań i przyznanych jej kompetencji. Zauważyć należy, iż owo formalne i materialne rozwarstwienie działań zewnętrznych wiąże się z mnogością i różnorodnością działań podejmowanych w ich ramach pozwalających określone wspólne cele osiągać. Obejmują one zarówno programowanie określonych polityk, jak też ich efektywne wdrażanie, czyli aktywności mieszczące się w zestawie funkcji tradycyjnie przypisywanych egzekutywie ${ }^{26}$. Warto jednak zauważyć, iż niezwykle istotnym elementem działań zewnętrznych Unii, jako wyodrębnionej traktatowo kategorii, pozostaje również działalność prawodawcza ${ }^{27}$. Ten ich element wydaje się jednak wymykać unijnej władzy wykonawczej. To w swej istocie wciąż działalność legislacyjna stanowiąca wszak inną gałąź władzy.

Wreszcie, wielości i zróżnicowaniu funkcji w ramach działań zewnętrznych UE towarzyszy różny poziom zaangażowania (i rola) unijnych instytucji w poszczególnych ich dziedzinach. W obszarze WPZiB dominującą rolę pełnią Rada Europejska i Rada, uprawnienia innych instytucji (np. Komisji) są tu wydatnie ograniczone. Jeśli jednak znów spojrzeć na działania zewnętrzne UE jako formalnie wyodrębnioną całość, okazuje się, iż poza nawiasem WPZiB zaangażowanie innych instytucji - przede wszystkim Komisji i Parlamentu Europejskiego (PE) - staje się nad wyraz dostrzegalne. Inną sprawą, ponownie, pozostaje kwestia charakteru, w jakim obie instytucje w tej materii występują. O ile w przypadku Komisji wydaje się, iż jej rola wpisuje się w działalność wykonawczą, o tyle uprawnienia PE wydają się posiadać charakter co do zasady ustawodawczy.

4. Sygnalizowana wyżej heterogeniczność działań zewnętrznych UE prowokuje pytania o ich spójność, a także ich efektywność. Być może wątpliwości w tej mierze byłoby mniej, gdyby wskazany obszar, funkcjonalnie mieszczący się w ramach unijnej egzekutywy, pozwalał się przypisać jednolitej, w miarę możliwości, organizacyjnie unijnej władzy wykonawczej. Stwierdzono jednak wyżej, iż ów jednolity instytucjonalny rdzeń tejże władzy jest w ramach Unii trudny do wyodrębnienia. Stąd niejednorodny charakter działań zewnętrznych UE jako pewnej kategorii może powodować zastrzeżenia co do ich koherencji.

Ustanowienie i ewolucja Wysokiego Przedstawiciela wydawało się swego rodzaju odpowiedzią na wyzwania generowane opisaną konstrukcją unijnych działań zewnętrznych. Zarówno podczas prac Konwentu w sprawie przyszłości Europy, jak

\footnotetext{
26 Por. m.in. regulacje traktatowe w zakresie WPZiB stanowiącej element działań zewnętrznych. W art. 26 ust. 1 i 2 czy 27 ust. 1 TUE mowa o opracowywaniu owej polityki, określaniu jej ogólnych wytycznych i strategicznych interesów. Artykuł 26 ust. 3 odwołuje się z kolei do kwestii jej implementacji. 27 Nie chodzi tu wyłącznie o akty przyjmowane w ramach WPZiB, lecz również o działalność czysto legislacyjną,
por. art. 207 ust. 2, art. 209 ust. 1, art. 212 ust. 2 czy art. 214 ust. 3 TFUE.
} 
i podczas negocjacji Traktatu z Lizbony (TL) ${ }^{28}$, konsekwentnie akcentowano potrzebę wzmocnienia pozycji WP i zapewnienia mu większej niezależności względem Rady i Prezydencji ${ }^{29}$. Miało to sprzyjać jednolitości reprezentacji i polityki zewnętrznej Unii. Przyjęte w tej mierze rozwiązania czynią z WP organ interesujący, organicznie powiązany ze sferą unijnych spraw zagranicznych, a także - instytucjonalnie i funkcjonalnie - $\mathrm{z}$ unijną egzekutywą.

Zauważyć wypada, iż Wysoki Przedstawiciel realizuje szereg funkcji w zakresie działań zewnętrznych UE (przypisywanych co do zasady egzekutywie), jakkolwiek gros jego aktywności koncentruje się wokół WPZiB jako kategorii szczególnej. Jednocześnie funkcje te wydają się korespondować z przywołanym wcześniej sposobem postrzegania egzekutywy - Wysoki Przedstawiciel wspólną politykę zagraniczną i bezpieczeństwa UE ,prowadzi, realizuje, wykonuje” (m.in. art. 18 ust. 2 i art. 24 ust. 1 TUE). Poprzez swoje propozycje przyczynia się także do jej opracowania (art. 18 ust. 2 TUE), w jej obszarze może również kierować do Rady wnioski w zakresie strategicznych celów i interesów Unii (art. 22 ust. 2 TUE) ${ }^{30}$.

Jakkolwiek WPZiB wydaje się naturalną przestrzenią Wysokiego Przedstawiciela, poza jej ramami aktywność WP pozostaje również wyraźnie dostrzegalna. Zauważyć wypada m.in., iż jest on odpowiedzialny za obowiązki Komisji w obszarze działań zewnętrznych. W ten sposób oddziaływać może na obszary działań zewnętrznych poza WPZiB w zakresie, w jakim stanowią one pole zainteresowania i kompetencji Komisji właśnie. WP obecny jest też w obszarach działań zewnętrznych podlegających Radzie. Wszystko to jest możliwe dzięki zastosowaniu określonego zabiegu - WP jest mianowicie jednym z wiceprzewodniczących Komisji (art. 18 ust. 4 TUE) i jednocześnie, z urzędu, przewodniczy Radzie ds. Zagranicznych (art. 18 ust. 3 TUE) ${ }^{31}$. Wysoki Przedstawiciel bierze również udział w pracach Rady Europejskiej (art. 15 ust. 2 TUE), co wydaje się zapewniać mu łączność z procesem politycznego decydowania na najwyższym unijnym szczeblu - także w szeroko rozumianym obszarze działań zewnętrznych.

W ten sposób owo interesujące osadzenie instytucjonalne WP umożliwia mu przyczynianie się do zapewniania i wzmacniania spójności różnych dziedzin unijnych działań zewnętrznych. Jest to obowiązkiem Unii i wobec podkreślanej już fragmentacji tych działań ma niebagatelne znaczenie. Wysoki Przedstawiciel czuwa nad spójnością unijnych działań zewnętrznych (art. 18 ust. 4 TUE), w tym zakresie

Traktat z Lizbony zmieniający Traktat o Unii Europejskiej i Traktat ustanawiający Wspólnotę Europejską podpisany w Lizbonie dnia 13 grudnia 2007 r., Dz.Urz. UE C 306 z 17.12.2017.

29 E. Denza, The Role of the High Representative of the Union for Foreign Affairs and Security Policy, (w:) H.-J. Blanke, S. Mangiameli (eds.), The European Union after Lisbon, Berlin Heidelberg 2012, s. 482-483.

30 WP pełni też funkcje reprezentacji zewnętrznej UE (w zakresie WPZiB), prowadzi w jej imieniu dialog polityczny ze stronami trzecimi oraz wyraża jej stanowiska na konferencjach i w organizacjach międzynarodowych, por. art. 27 ust. 2 TUE.

31 Por. Ch. Kaddous, Role and position of the High Representative of the Union for Foreign Affairs and Security Policy under the Lisbon Treaty, (w:) S. Griller, J. Ziller (eds.), The Lisbon Treaty. EU Constitutionalism without a Constitutional Treaty?, Wien 2008, s. 209-210. 
wspomaga także Radę i Komisję (art. 21 ust. 3 TUE), będąc zarazem członkiem obu instytucji. W efekcie, WP - poza wymiarem indywidualnie realizowanych funkcji - operuje w sferze działań zewnętrznych UE z poziomu Rady i Komisji. To, w założeniu konsolidujące, rozwiązanie może jednak generować szereg komplikacji natury praktycznej $^{32}$ i negatywnie wpływać na ,jakość" procesu formułowania i realizacji unijnej polityki zagranicznej. Nie wydaje się to jednak zmieniać faktu, iż utrwalona w TL koncepcja Wysokiego Przedstawiciela może być postrzegana jako właściwy krok w kierunku spójności działań zewnętrznych Unii. Warto jednak pamiętać, iż ich jednolitość, a także skuteczność nie zależy wyłącznie od istoty i sposobu funkcjonowania jednego z organów. Zasadnicze znaczenie w tej mierze ma całościowa konstrukcja ,polityki zagranicznej” Unii determinowana jej charakterem jako organizacji międzynarodowej.

5. Zaprezentowane uwagi wydają się potwierdzać, iż poszukiwanie w ramach Unii władzy wykonawczej nie jest wykluczone, choć aplikacja wzorców państwowych w tej materii musi specyfikę Unii uwzględniać. Specyfika ta powinna być również brana pod uwagę w analizach dotyczących działań zewnętrznych UE postrzeganych jako unijna polityka zagraniczna, gdyż tego rodzaju uproszczenie wymaga dokonania określonych zastrzeżeń. Wreszcie, nie budzi wątpliwości istnienie szeregu związków między unijną egzekutywą i działaniami zewnętrznymi. Jedną z możliwych ilustracji owych interesujących i wielopłaszczyznowych powiązań wydaje się Wysoki Przedstawiciel Unii ds. Zagranicznych i Polityki Bezpieczeństwa. Organ ten wydaje się bowiem przykładem ciała operującego w obszarze niezwykle zróżnicowanym wewnętrznie, realizującego w nim funkcje wykonawcze i stanowiącego czynnik konsolidujący działania zewnętrzne UE, wzmacniający ich spójność.

\section{BIBLIOGRAFIA}

Barcz Jan. 2010. Charakter prawny Unii Europejskiej. W Ustrój Unii Europejskiej, I-22-I40. Warszawa. Instytut Wydawniczy EuroPrawo.

Cardwell Paul James (ed.). 2012. EU External Relations Law and Policy in the Post-Lisbon Era. The Hague: T.M.C. Asser Press, Springer.

Conway Gerard. 2011. "Recovering a Separation of Powers in the European Union". European Law Journal Vol. 17, No. 3: 304-322.

Craig Paul. 2004. European Governance: Executive and Administrative Powers under the New Constitutional Settlement. W The EU Constitution in a Contextual Perspective, Jean Monnet Working Paper. http://jeanmonnetprogram.org/archive/papers/04/040501-12.pdf.

Denza Eileen. 2012. The Role of the High Representative of the Union for Foreign Affairs and Security Policy, 481-493. W The European Union after Lisbon. Berlin Heidelberg. Springer. 
Doliwa-Klepacki Zbigniew M. 1999. Encyklopedia Organizacji Międzynarodowych. Warszawa: Wydawnictwo 69.

Eeckhout Piet. 2011. EU External Relations Law. Oxford: Oxford University Press.

Góralczyk Wojciech, Sawicki Stefan. 2004. Prawo międzynarodowe publiczne w zarysie. Warszawa: LexisNexis.

Grzeszczak Robert. 2011. Władza wykonawcza w systemie Unii Europejskiej. Warszawa: Stowarzyszenie Absolwentów Wydziału Prawa i Administracji UW.

Grzeszczak Robert. 2011. „W poszukiwaniu locus władzy wykonawczej w Unii Europejskiej”. Nowa Politologia. http://www.nowapolitologia.pl/sites/default/files/articles/w-poszukiwaniu-locus -wladzy-wykonawczej-w-unii-europejskiej-540.pdf

Hix Simon, Høyland Bjørn. 2011. The Political System of the European Union. Basingstoke: Palgrave Macmillan.

Kaddous Christine. 2008. Role and position of the High Representative of the Union for Foreign Affairs and Security Policy under the Lisbon Treaty. W The Lisbon Treaty. EU Constitutionalism without a Constitutional Treaty?, 205-221. Wien New York. Springer.

Keukeleire Stephan, Delreux Tom. 2014. The Foreign Policy of the European Union. Basingstoke: Palgrave Macmillan.

Lenaerts Koen. 1991. "Some Reflections on the Separation of Powers in the European Community". Common Market Law Review Vol. 28 (1991): 11-35.

Lenaerts Koen, van Nuffel Piet, Bray Robert, Cambien Nathan. 2011. European Union Law. London: Sweet\&Maxwell

Nohlen Dieter (Hrsg.). 1998. Wörterbuch Staat und Politik. Bonn: Bundeszentrale für politische Bildung.

Poboży Monika. 2014. Zasada podziału władzy w systemie instytucjonalnym Unii Europejskiej. Warszawa: Oficyna Wydawnicza ASPRA-JR.

Woyke Wichard (Hrsg.). 1998. Handwörterbuch Internationale Politik. Bonn: Bundeszentrale für politische Bildung. 
Wysoki Przedstawiciel Unii ds. Zagranicznych i Polityki Bezpieczeństwa...

\section{HIGH REPRESENTATIVE OF THE UNION FOR FOREIGN AFFAIRS AND SECURITY POLICY - INTERSECTING EU EXECUTIVE AND EXTERNAL ACTION. SELECTED ISSUES}

The text provides a short analysis concerning EU executive power and its foreign policy. The latter is treated here as a part of traditionally defined executive. Relations between both categories are illustrated by an example of the High Representative. This organ seems to bind both fields being an executive body operating in - very differentiated - area of EU external action. The text is not aiming at exhaustive analysis of the problems mentioned above. Rather it's a set of reflections devoted only to selected issues.

Keywords: executive power, EU external action, High Representative

Słowa kluczowe: władza wykonawcza, działania zewnętrzne UE, Wysoki Przedstawiciel 